\title{
Nasal Cavity and Paranasal Sinuses Cancer pN2c TNM Finding v8
}

National Cancer Institute

\section{Source}

National Cancer Institute. Nasal Cavity and Paranasal Sinuses Cancer pN2c TNM Finding v8. NCI Thesaurus. Code C133065.

Nasal cavity and paranasal sinuses cancer with metastases in bilateral or contralateral lymph nodes, none larger than $6 \mathrm{~cm}$ in greatest dimension and ENE(-). (from AJCC 8th Ed.) 